\title{
The Effect of Rekattidiri Ovitrap towards Aedes aegypti Larval Density
}

\author{
Malik Saepudin', Soeharyo Hadisaputro ${ }^{2}$, Ari Suwondo ${ }^{3}$, Suhartono ${ }^{4}$ \\ ${ }^{1}$ Department of Environment Health, Politeknik Kesehatan Kemenkes, West Kalimantan, Indonesia \\ 1,2,3,4 Doctoral Program of Medical and Health Sciences, Faculty of Medicine, Universitas Diponegoro, \\ Semarang, Indonesia
}

\section{Article Info \\ Article history: \\ Received Jan 14, 2017 \\ Revised Feb 25, 2017 \\ Accepted Feb 28, 2017}

\section{Keyword:}

Aedes Larval Density

Dengue Hemorrhagic Fever

Endemic Sites

Intervention

Ovitrap

\begin{abstract}
Dengue Hemorrhagic Fever (DHF) is a health problem in Indonesia. The entire region of Indonesia at risk of contracting dengue disease. The study aims to prove the effect of modifications ovitrap rekattidiri on the density of larvae (HI: House Index, CI: Container Index and BI: Breteu Index) as well as comparing the differences between the mean larvae trapped between ovitrap Rekattidiri with standard ovitrap. Using a quasi experimental design, time series experimental design with Control group. Population subjects were Aedes aegypti at the endemic sites in Pontianak, West Borneo. The results showed larval density index in the intervention area decreased each ie HI from $26 \%$ to $3 \%$, CI of $6.95 \%$ to $2.19 \%$, and BI from $29 \%$ to $13 \%$. The number of larvae trapped in ovitrap rekattidiri ie $70 \%$ (12,770 larvae) more than the standard ovitrap in the control and intervention, namely: $17 \%(3,057$ larvae) and $13 \%(2,334$ larvae). It is concluded that there are significant modifications Rekattidiri ovitrap against larval density index (HI p-value: 0.025 , CI p-value: 0.052 , BI value of p: 0.04) and there are differences between the mean larvae trapped in ovitrap Rekattidiri and standard ovitrap with $\mathrm{p}$ value: 0.001
\end{abstract}

Copyright $\odot 2017$ Institute of Advanced Engineering and Science. All rights reserved.

\section{Corresponding Author:}

Malik Saepudin,

Doctoral Program of Medical and Health Sciences,

Faculty of Medicine, Universitas Diponegoro,

3-5 Imam Barjo, SH Road, Semarang 50242, Indonesia.

Email: malik_saepudin@yahoo.co.id

\section{INTRODUCTION}

Dengue Hemorrhagic Fever (DHF) is a serious public health problem in tropical and subtropical regions in America, Asia and Africa. World Health Organization (WHO) noted the number of dengue cases each year increased from 0.4 to 1.3 million a decade from 1996 to 2005, reaching 2.2 million in 2010 and 3.2 million in 2015 [1]. DHF is one of the health problems in Indonesian also. All of the regions throughout Indonesia have a high-risk for dengue fever, because both the virus and the mosquitoes are widespread in the settlements and public facilities throughout Indonesia.

Based on the recent available report, dengue fever has been being an endemic problem in 33 provinces and 436 districts or cities, 605 sub-districts and 1,800 villages. In the period of 2012 to 2013, it has reached a level of 41.25/100,000 population, with a Case Fatality Rate of 0.7\% [2]. One of the cities that has increase trend in dengue fever cases is Pontianak, West Borneo. The increase in dengue cases almost fourfold in 2014 (IR: 58.85), the mortality rate is still high (CFR: 4\%). The spread of dengue is evenly throughout all district in Pontianak. The number of people with the highest in 2014 is West Pontianak District 93 cases)[3]. Environmental conditions Pontianak City is located right on the Equator, with a height ranging from 0.10 to 1.50 meters above sea level, which is categorized as a low-lying (less than $500 \mathrm{~m}$ ) with high mosquito populations. Pontianak City temperature ranged from 26.8 to $28.8^{\circ} \mathrm{C}$, with the optimal 
temperature and rainfall. This range of temperatures is an ideal temperature $\left(20-30^{\circ} \mathrm{C}\right)$ for the life of Aedes aegypti. Rising temperatures shorten the extrinsic incubation period of the disease agent and tends to boost the pattern of spread of Dengue virus from time to time [4].

Dengue virus can grow and multiply without causing death to the mosquito because there is no cytopathic effect formed and it is an obligate intracellular parasite, which makes the virus able to only exist in living cells of a particularly suitable organism to live, so that the virus will only die if the living cells of the host die. The living cell of the hosting organism is called as host cell. The host cell here is the Aeides aegypti mosquito [5]. This is one of the factors affecting the availability and the ability of dengue virus to maintain its existence in nature, also the virus spread and defends themselves through two mechanisms: horizontal transmission between viremia vertebrates that is transmitted by the Aedes mosquito and vertical transmission (transovarial) in which the virus is infected by the female mosquitoes to the next generation [6]. Based on the descriptions above, it is necessary to have an innovative and complex control on the egg-larvae/larvae-pupaadult, so that the purpose of controlling the vector of Aedes spp mosquitoes can be realized and the case of the disease can aslo be controlled [7]. The specific control on the vector of dengue is aimed to reduce the density of Aedes mosquito population, and reducing the spread of the virus to a certain limit, so that there will have no potential to infect the dengue fever. The common sizes used are the three traditional Aedes indexes, namely House Index (HI), Container Index (CI), and Breteu Index (BI).

In controlling the dengue, WHO recommends some best ways are directed to the habitat located in a residential settlements [8]. One of the methods to control the Aedes aegypti vector without insecticides that succesfully reduce the vector density in some countries is the use of ovitrap. In this reseach is forming a kind of new ovitrap, Rekattidiri Ovitrap. The development of Rekattidiri Ovitrap is conducted to reduce the incidence and prevalence of dengue fever. Rekattidiri is an abbreviation of Merekat dan Mati Sendiri (being stuck and died by it). That is a combination between two modifications of Ovotitrap according to function, in one hand to catch the adult mosquitoes by sticking them on sticky ovitrap and on the other hand as an eggtrap that have a self-killing function (autocidal ovitrap). This combination can conduct these two functions are capturing the adult female gravid mosquitoes and killing the larvae after growing into adult at once, which is expected to create lower the larval density in dengue endemic areas.

\section{RESEARCH METHOD}

It is a quasi-experimental study employed the control group, time series experimental designs. The time series study often conducted to define the effect of intervention or medication [9]. The subject of this study is the Aedes aegyptimosquito in the study location. The population and sample of the subject cannot be found for its exact density, but can be measured by using the traditional Aedes indexes. The unit of this study is a group of houses/buildings in the selected study locations. The study unit is at the Village level. The selection subject techniqyue of study was conducted by using purposive sampling based on the guidelines index measurement larvae by the World Health Organization [8]. as well as also by five criteria; first, one of the villages with high endemic level of dengue in the last 4 years respectively; second, equal regional characteristics (conditions of settlements, vegetation, and topography); third, the occurrence of fatal dengue case(s) in the last four years; fourth, there is a new case in the last 3 months before the study conducted; fifth, has a distance $>5 \mathrm{~km}$ between the study locations (between the treatment and comparative locations). Based on those criterias above, there are two location in different Sub-Districts were selected. First location is located in Sungai Jawi Dalam Village of West Pontianak Sub-District as intervention group. Batu Layang Village of North Pontianak Sub-District is selected as control group. Each was selected 100 samples. For more details, in the intervention area ovitrap Rekattidiri use in Sungai Jawi Dalam Village of 100 homes around one of the houses that positive DHF. Ovitrap Rekattidiri and standard ovitrap placed side by side in every home adjusted by the number and location of shelters water (container). The total number ovitrap in the intervention are are 592 pieces. They are consisting of 119 pieces located inside the house, and 473 pieces outside the home. While the control group only placed 620 pieces, adjusted number of water reservoirs in the location.

Researcher was counting the number and type of reservoir in the study area to adjust the amount ovitrap that will be installed. Calculate the density of larvae (HI, CI, BI) before and after the installation of ovitrap Rekattidiri with, for 8 consecutive times at intervals of one week, 4 times before and four times after the intervention.Interventions carried out for two months (eight weeks), done counting the number of mosquitoes trapped in ovitrap Rekattidiri during the intervening eight times in succession with an interval of one week in the area of intervention, and compare with the standard ovitrap. This study has received ethical clearance from the Medical Research Ethics Committee of the Faculty of Medicine, University of Diponegoro with certificate number: 243/EC/FK-RSDK /2016. 


\section{RESULTS AND ANALYSIS}

This research was conducted in Dengue endemic areas in Pontianak City. The research location was selected by the endemicity criterias, they are; a new case found in the last 3 months, the occurrence of Case Fatality Rate in the last 3 years, and other criteria. Based on the criteria, there were 2 groups selected, they were treatment group in Sungai Jawi Dalam Village of West Pontianak Sub-District and comparative group in Batulayang Village of North Pontianak Sub-District.

The measurement was conducted on the indicators of Aedes aegypti larval density in the form of HI, BI, and CI, for 8 times; 4 times before and 4 times after the intervention. The results of the measurement on all larvae indexes showed that there are some decreases after the intervention (week 5) compared to the control group. The measurement on HI shows a decrease after the intervention from $26 \%$ to $3 \%$ as shown in Figure 1. CI decreased from $6.95 \%$ to $2.19 \%$ as shown in Figure 2. Likewise, the measurement on BI shows a decrease after the intervention in the fifth week from $29 \%$ to $13 \%$ as shown in Figure 3.

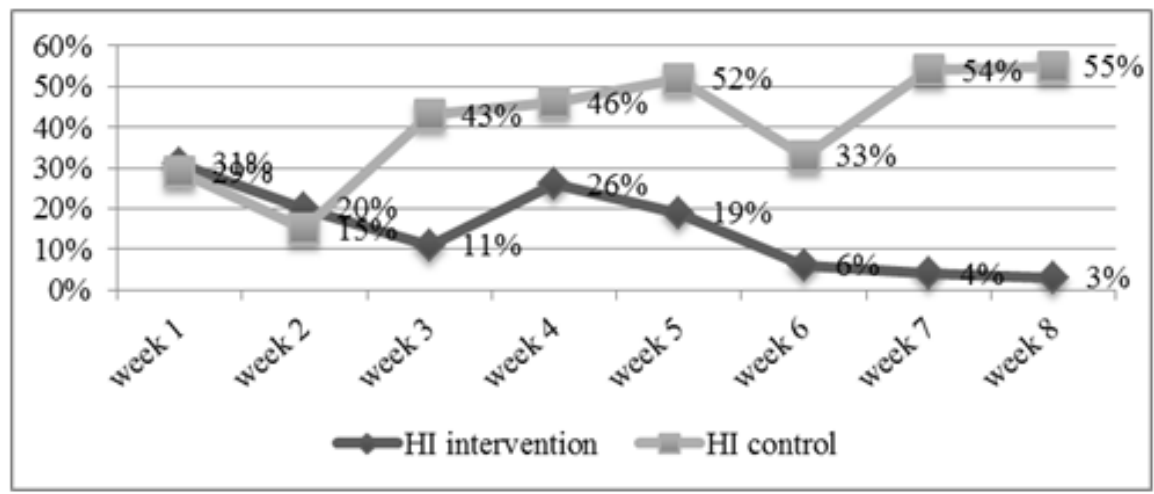

Figure 1. Comparison of HI before and after Intervention

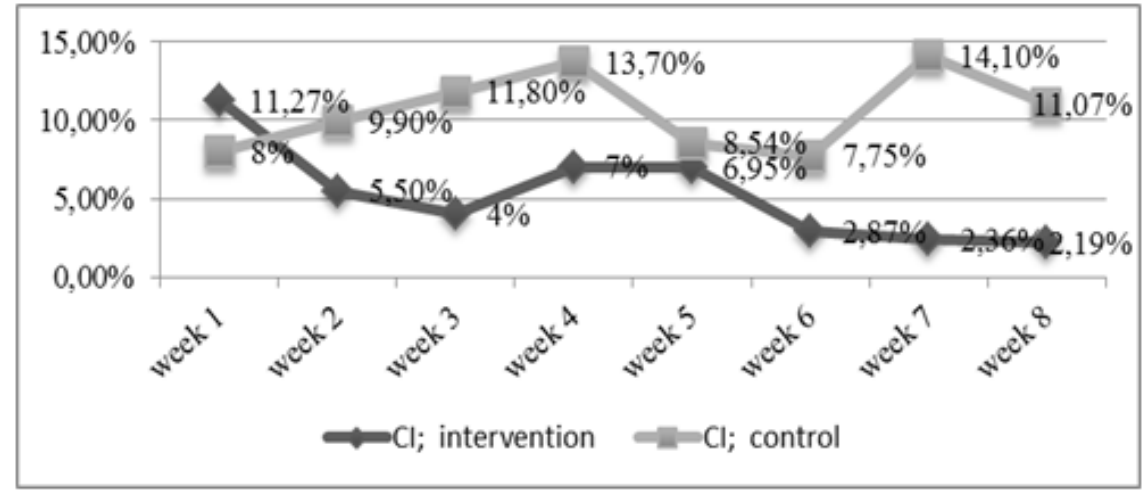

Figure 2. Comparison of CI before and after Intervention 


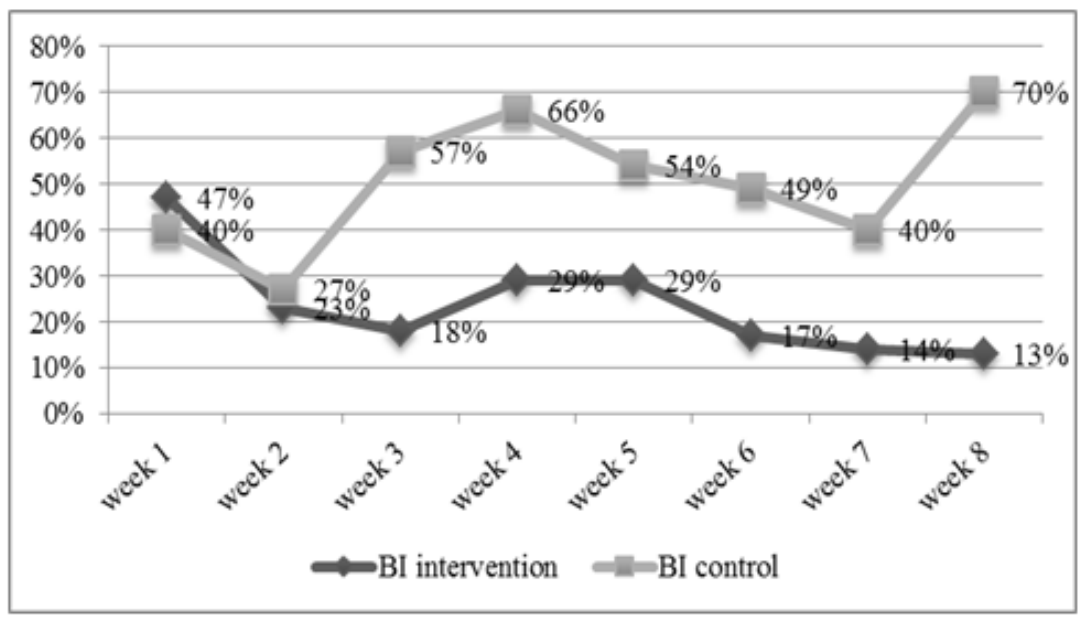

Figure 3. Comparison of BI before and after Intervention

The analysis on Figure 4 shows that the total number of larvae trapped in ovitrap Rekattidiri is 12,770 larvae, based on the differences between the mean numbers of larvae trapped in rekatidiri ovitrap was 1,596 larvae (70\%), ovitrap standard in the intervention area by 292 larvae (13\%) and ovitrap setandar in the region a comparison of 382 larvae $(17 \%)$. Kruskal Wallis test statistical test showed a significant difference in the mean larvae trapped ovitrap Rekattidiri and ovitrap setandar both in the intervention area or region of comparison, the value of p: 0.001 . Proceed with the Mann-Whitney test, shows that there are differences between the mean between Rekattidiri ovitrap with standard ovitrap either on the territory of both treatment and comparison is with $\mathrm{p}$ value: 0.002 and 0.005 . While the standard ovitrap at both sites showed no mean difference with $\mathrm{p}$ value: 0.093 . Based on the analysis of partial correlation (ry.x1x2) Rekattidiri ovitrap influence is very strong against the larval index with a value of r (HI: 0.889, CI: 0.998 and BI: 0.909), while the standard ovitrap have a weak influence with the value of r (HI: 0.650, CI: 0.290 and BI: 0.739)

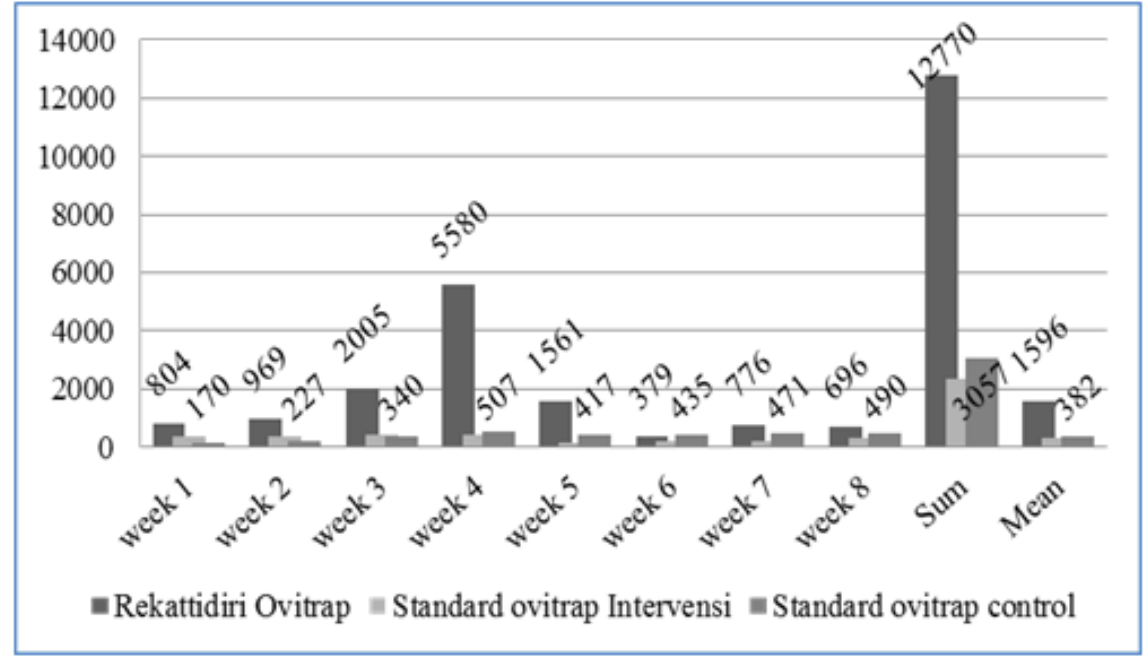

Figure 4. Distribution of The Mean Difference Larvae Trapped

The analysis on the paired data in Table 1 shows that there is a difference on the average of the measurement of larvae indicators (HI, CI, BI) before the treatment between the treatment and comparative group with a value of HI: 0.025 , CI: 0.045 , and BI: 0.052 . Than the analysis on the unpaired data in Table 2 shows that there is a difference on the average of the measurement of larvae indicators (HI, CI, BI) before the treatment between the treatment and comparative group with a value of HI: 0.000, CI: 0.010, and BI: 0.003 . 
Table 1. Analysis of Larvae and Transovarial Transmission Indexes on the Paired Data

\begin{tabular}{|c|c|c|c|c|c|c|c|}
\hline Group & Indicators & $\operatorname{Min}(\%)$ & $\operatorname{Max}(\%)$ & Mean (\%) & $\begin{array}{l}\text { standard } \\
\text { deviation }\end{array}$ & $\begin{array}{c}\text { amount } \\
(\%)\end{array}$ & p-value \\
\hline \multirow[t]{6}{*}{ Treatment } & HI pre & 11 & 31 & 22 & 9 & 88 & $0.025^{*}$ \\
\hline & HI Post & 3 & 19 & 8 & 7 & 32 & \\
\hline & BI pre & 18 & 47 & 29 & 13 & 117 & $0.052^{*}$ \\
\hline & BI Post & 13 & 29 & 18 & 7 & 73 & \\
\hline & CI pre & 4 & 11 & 7 & 3 & 28 & $0.045^{*}$ \\
\hline & CI Post & 2 & 7 & 4 & 2 & 15 & \\
\hline \multirow[t]{6}{*}{ Control } & HI pre & 15 & 46 & 33 & 14 & 133 & 0.068 \\
\hline & HI Post & 33 & 55 & 49 & 10 & 194 & \\
\hline & BI pre & 27 & 66 & 48 & 17 & 190 & 0.544 \\
\hline & BI Post & 40 & 70 & 53 & 13 & 213 & \\
\hline & CI pre & 8 & 14 & 11 & 2 & 43 & 0.704 \\
\hline & CI Post & 8 & 14 & 10 & 3 & 41 & \\
\hline
\end{tabular}

* Paires samples t test

Table 2. Analysis of Larvae and Transovarial Transmission Indexes on the Unpaired Data

\begin{tabular}{|c|c|c|c|c|c|c|c|}
\hline Group & Indicators & $\operatorname{Min}(\%)$ & $\operatorname{Max}(\%)$ & Mean $(\%)$ & $\begin{array}{l}\text { standard } \\
\text { deviation }\end{array}$ & $\begin{array}{c}\text { amount } \\
(\%)\end{array}$ & $p$-value \\
\hline \multirow[t]{6}{*}{ Pre Test } & HI Treatment & 11 & 31 & 22 & 9 & 88 & 0.225 \\
\hline & HI Control & 15 & 46 & 33 & 14 & 133 & \\
\hline & BI Treatment & 18 & 47 & 29 & 13 & 117 & 0.141 \\
\hline & BI Control & 27 & 66 & 48 & 17 & 190 & \\
\hline & CI Treatment & 4 & 11 & 7 & 3 & 28 & 0.097 \\
\hline & CI Control & 8 & 14 & 11 & 2 & 43 & \\
\hline \multirow[t]{6}{*}{ Post test } & HI Treatment & 3 & 19 & 8 & 7 & 32 & $0.000 *$ \\
\hline & HI Control & 33 & 55 & 49 & 10 & 194 & \\
\hline & BI Treatment & 13 & 29 & 18 & 7 & 73 & $0.003 *$ \\
\hline & BI Control & 40 & 70 & 53 & 13 & 213 & \\
\hline & CI Treatment & 2 & 7 & 4 & 2 & 15 & $0.010 *$ \\
\hline & CI Control & 8 & 14 & 10 & 3 & 41 & \\
\hline
\end{tabular}

*Independent samples t test

\subsection{Discussion}

The general overview of the resarch locations shows that the characteristics of endemicity and geographical environment and the population of the two sites before the study is relatively the same, especially the incidence of dengue cases is the main criterion determining the location of the study, showed that the incidence of dengue cases in the location that in April 2016, the difference in one week is incident cases in the intervention area in the 3rd week of April, while the region of the comparators in the 2nd week of April 2016. As a follow-up on the incident, has been pengedalian vectors such activities are conducted fogging and abatisasi selective focus [10]. Thus, the mosquito density conditions prior research activities are relatively the same, it is according to the results of research time series at week 1, indicating that the amount of larval density index is relatively the same in both locations comparative research that HI region of 29\% and $31 \%$ Intervention, CI territory Intervention comparator $6.32 \%$ and $7.93 \%$, and $\mathrm{BI}$ area comparator $40 \%$ and $47 \%$ Intervention.

Statistical analysis showed that there were significant differences in larval density indicators HI, CI and BI before and after treatment. Intervention for 8 weeks could prove Rekattidiri ovitrap influence on the density of larvae is a decline in the index of larvae of dengue high risk of transmission is low. In line with research conducted by Supakul in Thailand, after the installation of ovitrap four weeks showed not found larvae in ovitrap [11]. In line also with Sayono that there are significant modifications to the lethal ovitrap one indicator of the density of larvae (HI) [12]. However, in contrast to research Umniyati, that the modifications did not affect the ovitrap autocidal larval density [13]; based on the modifications made by Sayono autocidal and Umniyati, as well as the model developed by Eiras and Gama with adhesive paper (sticky) trap gravid female mosquitoes [14]-[15].

Ovitrap Rekattidiri has two functions: one side as a trap larvae and the other side as a gravid female traps Aedes spp. Modifications ovitrap Rekattidiri designed in accordance with the pleasure of Aedes spp laying namely black/dark, this part ovitrap lid opens partially to reduce the entry of direct sunlight. This is consistent with results of previous studies that Ae. Aegypti is more interested in putting their eggs in water reservoirs, dark/black, wide open and shielded direct sunlight [16]. The placement and number of ovitrap Rekattidiri adjusted by the amount and placement of the landfill in every home residents, according modification that ovitrap performed by Supakul in Thailand during May to September 2001, modifying the function installed in the bathroom or near the water tank and dispose of larvae that emerge every day [11]. 
The results of partial correlation analysis also addressed the relationship is very strong against the larval index, compared with ovitrap setandar. This is due to the towing/attractant in the form of water soaking hay undergo metabolic processes that produce substances such as ammonia and $\mathrm{CO}_{2}$ are able to attract the olfactory nerve Aedes mosquitoes to lay their eggs in these places [17]. With the use of behavior and bionomics of the Aedes mosquito, the ovitrap Rekattidiri with water soaking hay attractant quite effective in catching mosquitoes and reduce the population of Aedes spp. These results are consistent with research Polson and Santos which showed that the water soaking hay with a concentration of $10 \%$ to produce eggs of mosquitoes trapped for more [18]-[19]. Research Salim about ovitrap laboratory tests also showed that the attractant in the form of water immersion water straw is better than the former colonies [20]. The gravid female mosquitoes lay their eggs in place selective attractants containing compounds from the decay process of organic matter and bacteria is a good food source for mosquito larvae [21]-[22].

Based on the results showed the total number of mosquitoes trapped was 1,167 mosquitoes and larvae are caught are 12,770 larvae. If every adult mosquito laid 100 eggs [23], then it should be the number of mosquitoes that lay eggs and trapped for intervention is 128 mosquitoes, so the remaining 1,038 mosquitoes lay eggs but which have not been trapped at the sites. Thus ovitrap Rekattidiri could prevent as many as $1,038(89 \%)$ of mosquitoes will lay eggs in water containers. Than the results of the identification of the type of mosquitoes trapped in ovitrap Rekattidiri, indicating that the mosquitoes were discovered more is Aedes aegypti, as we know that the pleasure of resting mosquito Aedes aegypti is at home on the objects hanging [24]. The environment provides little chance for other species mosquito breeding. Although the number of mosquitoes trapped in ovitrap out is more at 65\% (764 head), than in that 35\% (403 head). It is also associated with the laying of the ovitrap with water jar, placed almost inseparable from the house that is on the side porch or the front of the house. Thus there is a pattern of behavior change that Aedes aegypti mosquitoes lay their eggs outside the houses. Limited breeding places in the house, causing the female mosquito Aedes aegypti gravid trying to find the nesting and their attractants in the ovitrap facilitate gravid female mosquitoes find new breeding places are ovitrap Rekattidiri in settlements where none previously existed [17],[25].

Use of ovitrap Rekattidiri with attractant can be used as an additional alternative in dengue vector control method. Rekattidiri ovitrap is a complete modification, compared with ovitrap designed by some previous researchers. Ovitrap serves a three-in-one, the first serves as autocidal ovitrap for collecting observation data vector density and the potential for vertical transmission/vertically in an area [6],[26]. Both functions are also as an adhesive/sticky ovitrap. Their adhesive on the upper side of the inner ovitrap catches female Aedes gravid. In accordance with the habits of the mosquito Aedes females gravid looking containers for nesting. So this model is very sensitive and suitable for use in epidemiological surveys and further study in the laboratory against several species of mosquitoes caught in sticky, so the integrated vector control programs and early detection of transmission can be done more quickly [14]-[15],[27]. The third function is as effective alternative vector control is mainly used after fogging focus and selective dissemination with temefos. According to the limitations and acceptance of society against fogging and abatisasi, as well as the affordability and the number of breeding sites around the globe (virtual index) are abundant in during the rainy season. Expectations of future government policy in this case the Ministry of Health, can use modification ovitrap Rekattidiri in Aedes aegypti vector control activities. And the additional to surveillance activities vector of dengue is not only focused on indicators entomologists like ABJ, but further enhanced the surveillance of the virus in the vector, as efforts to early arning systems (EWS) to prevent the occurrence of extraordinary events/epidemic [28].

\section{CONCLUSION}

Based on the data processing of research findings, in general it can be concluded that Ovitrap rekadiri interventions is capable being a mosquito trap on one of the dengue's endemic areas in Pontianak, West Borneo. This show from the results of processing statistical test that ovitrap Rekattidiri proved more effective than the standard ovitrap with $\mathrm{p}$ value: 0.001 . In addition, it also concluded this tool also able to reduce the larval index measurements in before and after the intervention. The findings of the index's decline larvae known based on statistical processing of the 3 measurements. The third measures are known also consistently affected by use of this tool. The measurement results are density index larvae House Index (HI), p value: 0.025; larvae Container Index (CI), p value: 0.052 and Breteu Index (BI), p value: 0.04 .

\section{ACKNOWLEDGMENTS}

The research was funded in part by Scholarships from the National Board of Health Human Resources, Ministry of Health of the Republic of Indonesia. The highest gratitude to The Pontianak City's 
Health Office, Dr. dr. Siti Rahmah Umniyati, SU, and Ema Zati Baroroh S.Psi for their contribution of this study.

\section{REFERENCES}

[1] WHO media center, "Dengue and dengue haemorrhagic fever," World Health Organization, 2016.

[2] www. Depkes.go.id, "Indonesia Dengue Situation In 2013," accessed on April 22, 2014.

[3] The Provincial Health Office of West Kalimantan, "Case Report Dengue Fever," 2014.

[4] Boewono D. T., et al., "Comprehensive Study of Prevention and Spatial Analysis of Transmission of Dengue Hemorrhagic Fever in the Region Salatiga," Proceedings of the Seminar Day: Vector and Reservoir Control Strategy on Natural Disaster Emergency in the Age of Decentralization, Salatiga, Research and Development and Reservoir Disease Vectors, pp. 98-115, 2006.

[5] S. Yotopranoto, et al., "Analisis Dinamika Populasi Vektor pada Lokasi dengan Kasus Demam Berdarah Dengue yang Tinggi di Kotamadya Surabaya," Majalah Kedokteran Tropis Indonesia, vol. 9, pp. 23-3, 1998.

[6] S. J. Mardihusodo, et al., "Proof of existence of Dengue Virus Transmission Vertically on Aedes spp. In the city of Yogyakarta," National Symposium on Aspects of Molecular Biology, Pathogenesis, Management and Prevention of outbreaks, Biotechnology Study Center UGM, Yogyakarta, 2007.

[7] D. J. Gubler, "The Global Emergence / Resurgence of arboviral Diseases as Public Health Problems," Arch Med Res., vol. 33, pp. 330, 2002.

[8] World Health Organization, "Prevention and Control of Dengue and Dengue Hemorrhagic Fever," Complete Guide, Translation: Palupi Widyastuti. Indonesian Editor: Salmiyatun. Moulds I., Jakarta, Book Medical Publishers EGC, pp. 58-77, 2005.

[9] D. T. Campbell and J. C. Stanley, "Experimental and Quasi-Experimental Designs for Research," Rnd McNally College Publishing Company, Chicago, 1973.

[10] The Ministry of Health of the Republic of Indonesia, "Prevention and Eradication of Dengue Haemorrhagic Fever in Indonesia," Jakarta, 2005.

[11] Supakul S. and Chitnumsup P., "Effectiveness of Control of Aedes aegypti Larvae by Using ovitrap and Larvatrap," J Trop Med Parasitol, vol. 24, pp. 43-48, 2001.

[12] Sayono, "Lethal Effect of Application of Its Modified ovitrap to Total Aedes Yang Trapped," Thesis, the Master of Epidemiology, University of Diponegoro in Semarang, 2008.

[13] Umniyati S. R., "Mechanical immunocytochemistry using monoclonal antibodies antidengue DSSC7 to study the pathogenesis of dengue virus infection and surveilansi vector," Dissertation, Graduate School, Health Sciences and Medicine, Gadjah Mada University, Yogyakarta, 2009.

[14] Gama R. A., et al., "Evaluation of the Sticky MosquiTRAPTM for Detecting Aedes (Stegomyia) aegypti (L.) (Diptera: Culicidae) during the Dry Season in Belo Horizonte, Minas Gerais, Brazil," Neotropical Entomology, vol/issue: 36(2), pp. 294- 302, 2007.

[15] Eiras A., "MosquiTRAP e AtrAEDES," 2007, accessed on December 27, 2016.

[16] B. Arif, "Ovitrap Color Difference Effect on Total Egg Aedes spp Trapped," Aspirator, vol. 2, 2010.

[17] Geier M., et al., "Ammonia as an attractant Component of Host Odour for the Yellow Fever Mosquito, Aedes aegypti," Chem Senses, vol. 24, pp. 647-653, 1999.

[18] Polson K. A., et al., "The Use of ovitrap Baited with Hay Infusion as a surveillance tool for Aedes aegypti Mosquitoes in Cambodia," Dengue Bulletin, vol. 26, pp. 178-184, 2002.

[19] Santos, et al., "Field Evaluation of ovitrap with Grass Infusion and Bacillus thuringiensis var israelensis to Determine Oviposition Rate of Aedes aegypti,” Dengue Bulletin, vol. 27, pp. 156-162, 2003.

[20] M. Salim, et al., "Pengaruh Atraktan pada Sticky Trap dan Lethal Ovitrap terhadap nyamuk Aedes aegypti (Diptera: Culicidai) Hasil kolonisasi Laboratorium,” Tesis, Universitas Gadjah Mada, Yogyakarta, 2011.

[21] Foster W. A. and E. D. Walker, "Medical and Veterinary Entomology," Edited by Gary Mullen and Lance Durden. London: Academic Press, pp. 203-233, 2002.

[22] J. D. Trexler, et al., "Field and Laboratory evaluations of ptenstial oviposition attractants for Aedes aegypti," Jurnal of the American Mosquito Control Association, vol/issue: 19(3), pp. 228-234, 2003.

[23] Silva I. G. and Silva H. H. G., "Lima CG. Ovipositional Behavior of Aedes aegypti (Diptera, Culicidae) in Different Strata and iological Cycle," Acta Biol Par.Curitiba, vol/issue: 32(1-4), pp. 1-8, 2003.

[24] Sutaryo, "Dengue," Medical Publishers, Faculty of Medicine, Yogyakarta, pp. 17-76, 2004.

[25] M. D. Bentley and J. F. Day, "Chemical Ecology and Behavior Aspects of Mosquito Oviposition," Annula Review of Entemology, vol/issue: 34(1), pp. 401-421, 1989.

[26] R. Norzahira, et al., "Ovitrap Surveillance of the dengue vector, Aedes (Stegomya) aegypti (L) and Aedes (Stegomya) albofictus Skuse in selected areas in Bentong, Pahang, Malasia," Tropical Biomedicine, vol/issue: 28(1), pp. 48-54, 2011.

[27] Ritchie S. A., et al., "An adulticidal Sticky ovitrap For Sampling Container-Breeding Mosquitoes," Journal of the American Mosquito Control Association, vol/issue: 19(3), pp. 235-242, 2003.

[28] Sucipto and C. Dani, "Detection of Dengue Virus Transmission transovarial At Aedes Aegypti," Journal of Health Sciences, Polytechnic Pontianak, vol/issue: 14(2), pp. 121-129, 2012. 